\title{
Maximal exercise at extreme altitudes on Mount Everest
}

\author{
J. B. WEST, S. J. BOYER, D. J. GRABER, P. H. HACKETT, K. H. MARET, \\ J. S. MILLEDGE, R. M. PETERS, JR., C. J. PIZZO, M. SAMAJA, \\ F. H. SARNQUIST, R. B. SCHOENE, AND R. M. WINSLOW \\ American Medical Research Expedition to Everest, and Section of Physiology, \\ Department of Medicine, University of California, San Diego, La Jolla, California 92093
}

WeST, J. B., S. J. BOYER, D. J. GRABER, P. H. HACKeTT, K. H. Maret, J. S. Milledge, R. M. Peters Jr., C. J. Pizzo, M. Samaja, F. H. SaRnquist, R. B. Schoene, and R. M. Winslow. Maximal exercise at extreme altitudes on Mount Everest. J. Appl. Physiol.: Respirat. Environ. Exercise Physiol. 55(3): 688-698, 1983.-Maximal exercise at extreme altitudes was studied during the course of the American Medical Research Expedition to Everest. Measurements were carried out at sea level [inspired $\mathrm{O}_{2}$ partial pressure $\left(\mathrm{Po}_{2}\right) 147$ Torr], 6,300 $\mathrm{m}$ during air breathing (inspired $\mathrm{Po}_{2} 64$ Torr), 6,300 $\mathrm{m}$ during $16 \% \mathrm{O}_{2}$ breathing (inspired $\mathrm{Po}_{2} 49$ Torr), and 6,300 $\mathrm{m}$ during $14 \% \mathrm{O}_{2}$ breathing (inspired $\mathrm{Po}_{2} 43$ Torr). The last $\mathrm{Po}_{2}$ is equivalent to that on the summit of Mt. Everest. All the 6,300 $\mathrm{m}$ studies were carried out in a warm well-equipped laboratory on well-acclimatized subjects. Maximal $\mathrm{O}_{2}$ uptake fell dramatically as the inspired $\mathrm{PO}_{2}$ was reduced to very low levels. However, two subjects were able to reach an $\mathrm{O}_{2}$ uptake of $1 \mathrm{l} /$ min at the lowest inspired $\mathrm{Po}_{2}$. Arterial $\mathrm{O}_{2}$ saturations fell markedly and alveolar-arterial $\mathrm{Po}_{2}$ differences increased as the work rate was raised at high altitude, indicating diffusion limitation of $\mathrm{O}_{2}$ transfer. Maximal exercise ventilations exceeded $200 \mathrm{l} / \mathrm{min}$ at $6,300 \mathrm{~m}$ during air breathing but fell considerably at the lowest values of inspired $\mathrm{Po}_{2}$. Alveolar $\mathrm{CO}_{2}$ partial pressure was reduced to 7-8 Torr in one subject at the lowest inspired $\mathrm{PO}_{2}$, and the same value was obtained from alveolar gas samples taken by him at rest on the summit. The results help to explain how man can reach the highest point on earth while breathing ambient air.

hypoxemia; diffusion impairment; hyperventilation; respiratory alkalosis; oxygen uptake

THE SEVERE HYPOXIA of extreme altitudes such as the summit of Mt. Everest puts resting man near his limit of tolerance. When $\mathrm{O}_{2}$ transfer is additionally stressed by exercise, pulmonary gas exchange becomes even more critical. The $\mathrm{O}_{2}$ partial pressure $\left(\mathrm{PO}_{2}\right)$ of inspired air on the summit is only 43 Torr (26), resulting in a resting arterial $\mathrm{PO}_{2}$ of less than 30 Torr (24). Although climbers have reached the summit breathing ambient air $(12,15)$, their accounts clearly show how close they are to the limit of human performance.

Available data on maximal $\mathrm{O}_{2}$ uptake at somewhat lower altitudes (21) suggest that almost all the $\mathrm{O}_{2}$ that is available on the summit will be required for basal metabolism. Theoretical analyses $(8,27)$ suggest that the maximal $\mathrm{O}_{2}$ uptake of a climber on the summit could not exceed about $550-700 \mathrm{ml} / \mathrm{min}$. It is questionable whether man could climb to the summit with such a severe restriction. Those studies identified several critical gaps in our knowledge which the present investigation was designed to fill.

This paper reports exercise studies carried out during the course of the American Medical Research Expedition to Everest, which took place in the fall of 1981. A sophisticated laboratory was set up at an altitude of $6,300 \mathrm{~m}$, barometric pressure 351 Torr. Subjects were studied both while breathing ambient air and while inhaling low $\mathrm{O}_{2}$ mixtures containing 16 and $14 \% \mathrm{O}_{2}$. These mixtures gave virtually the same inspired $\mathrm{Po}_{2}$ as that of climbers at altitudes of $8,050 \mathrm{~m}$ (barometric pressure 283 Torr) and at the summit of Mt. Everest, altitude 8,848 m (barometric pressure 253 Torr). The study elucidates how it is possible for man to reach an $\mathrm{O}_{2}$ uptake of $1 \mathrm{l} /$ min at the highest point on earth.

\section{METHODS}

\section{Subjects}

There were 15 members of the expedition, and anthropometric data are given in Table 1 . Note that two weights are given. The first is for the base-line studies carried out at sea level in La Jolla in May 1981 prior to the expedition, and the second is the weight during the measurements at $6,300 \mathrm{~m}$ in October of the same year. Body weight usually falls at these high altitudes due to a combination of loss of appetite, impaired absorption, indifferent food, and possibly some dehydration. The subjects had been at altitudes of $5,400 \mathrm{~m}$ (barometric pressure 400 Torr) or higher for about 5 wk before the 6,300-m measurements were made.

Many of the subjects were unusually athletic. For example, of the six subjects $(S B, C P, R S, F S, D G$, and $P H)$ who took part in the studies at $6,300 \mathrm{~m}$ while breathing $16 \% \mathrm{O}_{2}$, the first four were competitive marathon runners. This group also included both of the subjects $(C P$ and $R S$ ) who took part in the studies while breathing $14 \% \mathrm{O}_{2}$. In addition two other subjects shown in Table 1 regularly competed in long-distance running. Two of the subjects ( $J M$ and $J W$ ) were not particularly athletic, but they had previously participated in studies of maximal work capacity at altitudes up to 6,400 and $7,440 \mathrm{~m}$ during the Himalayan Scientific and Mountaineering Expedition 1960-1961 (21). All subjects gave informed consent for the procedures.

0161-7567/83 \$1.50 Copyright ( 1983 the American Physiological Society 
TABLE 1. Anthropometric data

\begin{tabular}{|c|c|c|c|c|}
\hline \multirow{2}{*}{ Subj } & \multirow{2}{*}{$\begin{array}{l}\text { Age, } \\
\text { yr }\end{array}$} & \multirow{2}{*}{$\begin{array}{c}\text { Height, } \\
\text { cm }\end{array}$} & \multicolumn{2}{|c|}{ Weight, kg } \\
\hline & & & Sea level & $6,300 \mathrm{~m}$ \\
\hline$F B$ & 47 & 188 & 92.8 & 77.5 \\
\hline$S B$ & 34 & 175 & 67.6 & 66.0 \\
\hline$J E$ & 42 & 179 & 85.5 & 81.9 \\
\hline$D G$ & 30 & 193 & 85.8 & 79.5 \\
\hline$P H$ & 33 & 179 & 67.8 & 59.3 \\
\hline$D J$ & 33 & 179 & 72.1 & 65.3 \\
\hline$C K$ & 33 & 179 & 78.6 & 74.2 \\
\hline$J M$ & 51 & 175 & 69.2 & 64.2 \\
\hline$R P$ & 25 & 183 & 63.6 & 63.2 \\
\hline$C P$ & 31 & 183 & 70.8 & 65.9 \\
\hline$G P$ & 33 & 171 & 73.0 & 56.0 \\
\hline$F S$ & 38 & 169 & 67.2 & 65.4 \\
\hline$R S$ & 34 & 179 & 77.2 & 74.5 \\
\hline$M W$ & 31 & 175 & 72.0 & 71.0 \\
\hline$J W$ & 52 & 183 & 78.8 & 70.1 \\
\hline
\end{tabular}

Sea-level measurements were made at La Jolla in May 1981; 6,300$m$ measurements in October 1981.

\section{Exercise Studies}

The exercise studies were carried out in a comfortable laboratory (Weatherport, Gunniston, CO) constructed of fiberglass blankets covering an aluminum frame. The dimensions were $2.4 \mathrm{~m}$ wide by $4.6 \mathrm{~m}$ long by $2.1 \mathrm{~m}$ high, and there was a plywood floor. The laboratory was kept warm $\left(10-20^{\circ} \mathrm{C}\right)$ with a propane heater and provided with electrical power and light from a bank of lead acid batteries charged by a gasoline generator and solar panels; $110 \mathrm{~V} \mathrm{AC}$ were obtained from inverters. A brief description of the instrumentation has been published elsewhere (14).

The subjects exercised on a portable bicycle ergometer identical in design to that used on the 1960-1961 expedition $(21,23)$. The subjects pedaled at $50 \mathrm{rpm}$ up to a work level of $900 \mathrm{~kg} \cdot \mathrm{m} \cdot \mathrm{min}^{-1}$ but at $75 \mathrm{rpm}$ at higher work levels. The timing was provided by a metronome which was checked before each run. After an initial warm-up period of at least $10 \mathrm{~min}$ at $300 \mathrm{~kg} \cdot \mathrm{m} \cdot \mathrm{min}^{-1}$ the required work rate was selected by adjusting the load on the bicycle brake band. The load was continually checked by one observer during each run. The required work rate was maintained for $5 \mathrm{~min}$ at loads up to 900 $\mathrm{kg} \cdot \mathrm{m} \cdot \mathrm{min}^{-1}$ at sea level and $3 \mathrm{~min}$ at higher work rates. For the studies at 6,300 $\mathrm{m}$ during ambient air breathing, the duration was $3 \mathrm{~min}$ for work levels above $600 \mathrm{~kg} \cdot \mathrm{m}$. $\min ^{-1}$ and for the studies in which low $\mathrm{O}_{2}$ mixtures were inhaled, all the work durations were $3 \mathrm{~min}$.

The valve box (Koegel, San Antonio, TX) had a low resistance and the circuit was made of plastic tubing of $3.8-\mathrm{cm}$ bore. During the last minute $(2 \mathrm{~min}$ for the 300 $\mathrm{kg} \cdot \mathrm{m} \cdot \mathrm{min}^{-1} \mathrm{load}$ ) expired gas was collected in a meterological balloon and analyzed within a few minutes using $\mathrm{O}_{2}$ and $\mathrm{CO}_{2}$ meters (Beckman Instruments, models OM11 and LG2, respectively). The analyzers were calibrated before and after each gas analysis by sampling from tanks of calibrating gases. The outputs of the $\mathrm{O}_{2}$ and $\mathrm{CO}_{2}$ analyzers were displayed on a strip-chart recorder (Gould model 222). Following the gas analysis, the remainder of the gas was passed through a dry gas meter (Singer, Warren Collins) for the measurement of volume. Allowance was made for the small amount of gas which passed through the analyzers.

During exercise the electrocardiogram (Lumiscope) was continuously recorded on one channel of a stripchart recorder so that heart rate could be determined. The leads were placed in the CM5 configuration. Arterial $\mathrm{O}_{2}$ saturation was continuously measured by ear oximeter (Hewlett Packard) and displayed on another channel of a strip-chart recorder. The oximeter output was directly calibrated against arterial blood in three subjects ( $J E$, $J M$, and $J W$ ); six samples of blood were taken, three while the subjects breathed a low $\mathrm{O}_{2}$ concentration, but one of the samples was spilled prior to analysis. $\mathrm{O}_{2}$ saturation was measured by a new technique in which the $\mathrm{Po}_{2}$ of the blood was observed when its saturation was altered by adding potassium ferricyanate (Winslow and Samaja; unpublished observations). Figure 1 shows the results of the oximeter calibration done at $6,300 \mathrm{~m}$.

Exercise studies were also carried out with some of the subjects breathing low $\mathrm{O}_{2}$ concentrations in the laboratory at $6,300 \mathrm{~m}$. In the first series (6 subj), the inspired $\mathrm{O}_{2}$ concentration was $16.0 \%$. This gave an inspired $\mathrm{Po}_{2}$ of 48.5 Torr to match that existing at Camp 5 just above the South Col of Mt. Everest (alt 8,050 m, barometric pressure 280 Torr). ${ }^{1}$ Two subjects performed maximal exercise breathing $14.0 \% \mathrm{O}_{2}$ which reduced the inspired $\mathrm{Po}_{2}$ to 42.5 Torr. This was designed to be equivalent to the inspired $\mathrm{PO}_{2}$ on the summit of Mt. Everest (alt 8,848 $\mathrm{m}$, barometric pressure 250 Torr). ${ }^{2}$ The low $\mathrm{O}_{2}$ mixtures were prepared by having subjects exercise at a moderate rate on the bicycle ergometer and then collecting the expired gas in large balloons after passing it through a $\mathrm{CO}_{2}$ absorber. The absence of $\mathrm{CO}_{2}$ was checked with the $\mathrm{CO}_{2}$ analyzer. The $\mathrm{O}_{2}$ concentration was titrated to the correct level by rebreathing some of the gas once more, or diluting it with ambient air.

Barometric pressure was measured with a crystal sensor barometer checked against a mercury barometer kept at Base Camp (26). Venous blood samples were taken in three subjects before and after maximal exercise at 6300 $\mathrm{m}$ (air breathing) for measurements of lactate, hemoglobin, and hematocrit. The samples were removed from an arm vein $7 \mathrm{~min}$ after the end of exercise.

\section{Ambulatory Measurements}

Measurement of exercise ventilation and heart rate were made in two subjects while they were climbing at their maximum rate en route to the summit from the top camp. They breathed ambient air for these studies though for the rest of the climb they were breathing from an $\mathrm{O}_{2}$ mask (inspired $\mathrm{PO}_{2}$ about 70 Torr). Ventilation was measured by having the subject breathe through a turbine flowmeter of low resistance (Boehringer Laboratories). Rotation of the turbine interrupted a light beam, and the resulting pulses were recorded on one channel of a slow-running tape recorder (Medilog, Oxford Instruments). A second channel recorded tempera-

\footnotetext{
${ }^{1}$ We subsequently found that the mean barometric pressure at Camp 5 was slightly higher at 283.6 Torr (26).

${ }^{2}$ Again, the actual pressure on the summit was a little higher at 253.0 Torr (26).
} 
ture from a thermistor in the flow meter. Electrocardiogram recordings were made continuously from electrodes in the CM5 configuration and recorded on another channel. The fourth channel had timing pulses and also encoded information from an event marker, which the climber operated to indicate what he was doing. He also had a miniature dictating tape recorder to keep a log of his activities.

\section{RESULTS}

Table 2 shows the means of the results of all the exercise measurements. The table is divided into four sections. The first shows the studies done at sea level at the University of California, San Diego, in May, 1981.

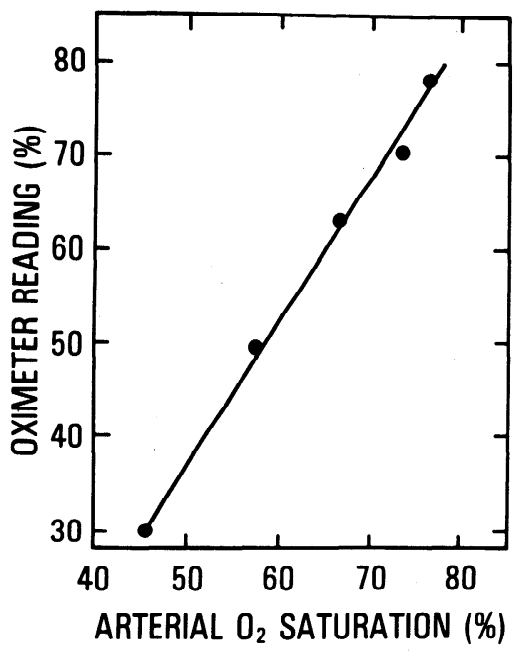

FIG. 1. Calibration of ear oximeter at $6,300 \mathrm{~m}$. Five blood samples were taken from 3 subjects, 2 of whom breathed both air and a low $\mathrm{O}_{2}$ mixture.
The second study was carried out in the Camp 2 laboratory in October during the expedition. The third and fourth sets of measurements were done in the same laboratory but with the subject inhaling 16 and $14 \% \mathrm{O}_{2}$ mixtures, respectively.

\section{Work Rate}

Sea level. Table 2 shows that seven of the subjects $(S B$, $J E, D G, C K, C P, F S$, and $R S$ ) were able to work for 3 min at the rate of $2,100 \mathrm{~kg} \cdot \mathrm{m} \cdot \mathrm{min} .^{-1}$ Actually one other subject $(M W)$ also completed $3 \mathrm{~min}$ at this work level, but an error in the gas collection invalidated the results. Five subjects $(S B, D G, C K, C P$, and $R S$ ) were able to work at the rate of $2,400 \mathrm{~kg} \cdot \mathrm{m} \cdot \mathrm{min}^{-1}$, though only one completed the $3 \mathrm{~min}$, the others being exhausted after 2 $\min$.

These work levels are relatively high, particularly as most of the subjects had not trained on a bicycle ergometer. Although the values are not as high as those found in some trained athletes $(2,18)$, they are substantially higher than those reported by Pugh et al. (21) in a previous study at extreme altitudes with which our study has many similarities. In that study only three subjects could work at sea level at a rate exceeding $1,500 \mathrm{~kg} \cdot \mathrm{m} \cdot$ $\min ^{-1}$ (the values were in the range $1,800-2,000 \mathrm{~kg} \cdot \mathrm{m}$. $\min ^{-1}$ ) and the highest measured $\mathrm{O}_{2}$ uptake was $3.93 \mathrm{l} /$ min as opposed to $4.63 \mathrm{l} / \mathrm{min}$ in the present study.

$6,300 \mathrm{~m}$ altitude. Eight subjects ( $S B, J E, D G, C K, C P$, $R P, R S$, and $M W$ ) were able to work at a rate of 1,200 $\mathrm{kg} \cdot \mathrm{m} \cdot \mathrm{min}^{-1}$ for $3 \mathrm{~min}$ while breathing ambient air. When a gas mixture containing $16 \% \mathrm{O}_{2}$ was inhaled at that altitude, all six subjects in that study $(S B, D G, P H, C P$, $F S$, and $R S$ ) were able to work at $450 \mathrm{~kg} \cdot \mathrm{m} \cdot \mathrm{min}^{-1}$ and three subjects $(S B, D G$, and $C P$ ) completed 3 min at 600 $\mathrm{kg} \cdot \mathrm{m} \cdot \mathrm{min}^{-1}$. The maximum work rate for $3 \mathrm{~min}$ while

TABLE 2. Summary of exercise results

\begin{tabular}{|c|c|c|c|c|c|c|c|c|c|c|c|c|}
\hline \multirow{2}{*}{$\begin{array}{l}\text { Altitude, } \mathrm{PB} \\
\text { Insp } \mathrm{O}_{2}\end{array}$} & \multirow[b]{2}{*}{$n$} & \multirow{2}{*}{$\begin{array}{l}\text { Work Rate, } \\
\mathrm{kg} \cdot \mathrm{m} \cdot \mathrm{min}^{-1}\end{array}$} & \multirow{2}{*}{$\begin{array}{l}\dot{\mathrm{V}} \mathrm{o}_{2} \\
\mathrm{l} / \mathrm{min}\end{array}$} & \multicolumn{2}{|c|}{ Ventilation, $1 / \min$} & \multirow{2}{*}{$\begin{array}{l}\text { Resp } \\
\text { Fre- } \\
\text { quency, } \\
\text { breaths/ } \\
\text { min }\end{array}$} & \multirow{2}{*}{$\mathrm{FE}_{\mathrm{O} 2}, \%$} & \multirow{2}{*}{$\mathrm{FE}_{\mathrm{CO}_{2}}, \%$} & \multirow{2}{*}{$\mathbf{R}$} & \multicolumn{2}{|c|}{$\mathrm{O}_{2}$ Saturation* } & \multirow{2}{*}{$\begin{array}{c}\text { Heart } \\
\text { Rate, } \\
\text { beats/min }\end{array}$} \\
\hline & & & & STPD & BTPS & & & & & Start & End & \\
\hline $\begin{array}{l}\text { Sea level } \\
\quad(750 \text { Torr }) \\
\mathrm{PI}_{\mathrm{O}_{2}}=147.1 .\end{array}$ & $\begin{array}{r}14 \\
14 \\
14 \\
14 \\
11 \\
7 \\
5\end{array}$ & $\begin{array}{r}300 \\
600 \\
900 \\
1,500 \\
1,800 \\
2,100 \\
2,400\end{array}$ & $\begin{array}{l}0.99 \\
1.52 \\
2.14 \\
3.24 \\
3.83 \\
4.37 \\
4.63\end{array}$ & $\begin{array}{r}20.0 \\
29.1 \\
41.5 \\
71.2 \\
101.7 \\
107.7 \\
130.7\end{array}$ & $\begin{array}{r}24.8 \\
37.2 \\
50.9 \\
87.4 \\
123.8 \\
132.0 \\
160.2\end{array}$ & $\begin{array}{l}17 \\
18 \\
23 \\
31 \\
41 \\
38 \\
52\end{array}$ & $\begin{array}{l}16.15 \\
15.78 \\
15.87 \\
16.32 \\
16.96 \\
16.75 \\
17.29\end{array}$ & $\begin{array}{l}4.15 \\
4.45 \\
4.53 \\
4.46 \\
4.09 \\
4.41 \\
3.82\end{array}$ & $\begin{array}{l}0.85 \\
0.84 \\
0.88 \\
0.98 \\
1.06 \\
1.07 \\
1.06\end{array}$ & $\begin{array}{l}97 \\
97 \\
98 \\
97 \\
97 \\
97 \\
95\end{array}$ & $\begin{array}{l}97 \\
97 \\
97 \\
97 \\
97 \\
95 \\
95\end{array}$ & $\begin{array}{r}95 \\
109 \\
125 \\
155 \\
172 \\
174 \\
178\end{array}$ \\
\hline $\begin{array}{l}6,300 \mathrm{~m} \\
\quad(351 \text { Torr }) \\
\mathrm{PI}_{\mathrm{O}_{2}}=63.7\end{array}$ & $\begin{array}{r}14 \\
14 \\
12 \\
8\end{array}$ & $\begin{array}{r}300 \\
600 \\
900 \\
1,200\end{array}$ & $\begin{array}{l}0.79 \\
1.34 \\
1.90 \\
2.31\end{array}$ & $\begin{array}{l}19.1 \\
32.9 \\
53.3 \\
73.1\end{array}$ & $\begin{array}{r}54.1 \\
93.2 \\
151.0 \\
207.2\end{array}$ & $\begin{array}{l}30 \\
43 \\
49 \\
62\end{array}$ & $\begin{array}{l}16.77 \\
16.83 \\
17.17 \\
17.52\end{array}$ & $\begin{array}{l}3.89 \\
4.10 \\
4.19 \\
4.10\end{array}$ & $\begin{array}{l}0.92 \\
1.00 \\
1.15 \\
1.27\end{array}$ & $\begin{array}{l}70 \\
67 \\
64 \\
62\end{array}$ & $\begin{array}{l}69 \\
66 \\
64 \\
59\end{array}$ & $\begin{array}{l}108 \\
127 \\
134 \\
146\end{array}$ \\
\hline $\begin{array}{l}6,300 \mathrm{~m} \\
\mathrm{FI}_{\mathrm{O}_{2}}=0.16 \\
\mathrm{PI}_{\mathrm{O}_{2}}=48.5\end{array}$ & $\begin{array}{l}6 \\
6 \\
6\end{array}$ & $\begin{array}{l}300 \\
450 \\
600\end{array}$ & $\begin{array}{l}0.84 \\
1.21 \\
1.45\end{array}$ & $\begin{array}{l}29.2 \\
43.1 \\
55.8\end{array}$ & $\begin{array}{r}83.1 \\
122.5 \\
158.8\end{array}$ & $\begin{array}{l}38 \\
51 \\
63\end{array}$ & $\begin{array}{l}12.91 \\
13.06 \\
13.15\end{array}$ & $\begin{array}{l}3.61 \\
3.34 \\
3.53\end{array}$ & $\begin{array}{l}1.28 \\
1.18 \\
1.35\end{array}$ & $\begin{array}{l}58 \\
53 \\
55\end{array}$ & $\begin{array}{l}56 \\
53 \\
55\end{array}$ & $\begin{array}{l}121 \\
127 \\
128\end{array}$ \\
\hline $\begin{aligned} 6,300 \mathrm{~m} \\
\mathrm{FI}_{\mathrm{O}_{2}}=0.14 \\
\mathrm{PI}_{\mathrm{O}_{2}}=42.5\end{aligned}$ & $\begin{array}{l}2 \\
2 \\
2\end{array}$ & $\begin{array}{l}150 \\
300 \\
450\end{array}$ & $\begin{array}{l}0.69 \\
1.07 \\
0.99\end{array}$ & $\begin{array}{l}27.6 \\
47.8 \\
57.0\end{array}$ & $\begin{array}{r}78.4 \\
135.9 \\
161.9\end{array}$ & $\begin{array}{l}69 \\
77 \\
80\end{array}$ & $\begin{array}{l}11.40 \\
11.59 \\
11.59\end{array}$ & $\begin{array}{l}3.16 \\
2.98 \\
2.91\end{array}$ & $\begin{array}{l}1.24 \\
1.26 \\
1.62\end{array}$ & $\begin{array}{l}61 \\
52 \\
51\end{array}$ & $\begin{array}{l}58 \\
54 \\
46\end{array}$ & $\begin{array}{l}114 \\
135 \\
129\end{array}$ \\
\hline
\end{tabular}

$n$, No. of subjects. $\mathrm{V}_{2}, \mathrm{O}_{2}$ uptake; $\mathrm{FE}_{\mathrm{O}_{2}}$, expired $\mathrm{O}_{2}$ fraction; $\mathrm{FE}_{\mathrm{CO}_{2}}$, expired $\mathrm{CO}_{2}$ fraction; $\mathrm{R}$, respiratory exchange ratio; $\mathrm{PI}_{\mathrm{O}_{2}}$, partial pressure of inspired $\mathrm{O}_{2}$; $\mathrm{FI}_{\mathrm{O}_{2}}$, inspired $\mathrm{O}_{2}$ fraction. $\quad *$ Measured in the first and last minute of exercise. 


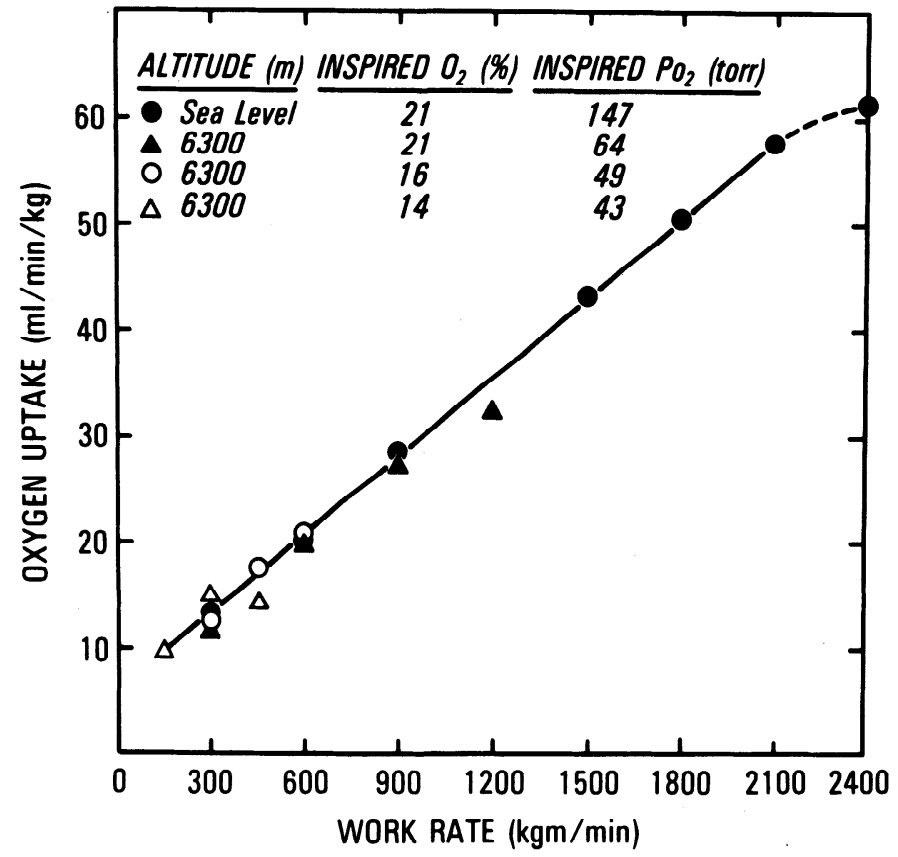

FIG. 2. $\mathrm{O}_{2}$ uptake $\left(\mathrm{ml} \cdot \mathrm{min}^{-1} \cdot \mathrm{kg}\right.$ body $\left.\mathrm{wt}^{-1}\right)$ against work rate. Points are mean values. Regression line was drawn through sea-level data. Open triangles $\left(6,300 \mathrm{~m}, 14 \% \mathrm{O}_{2}\right)$ represent inspired $\mathrm{Po}_{2}$ on summit of Mt. Everest.

breathing $14 \% \mathrm{O}_{2}$ was $450 \mathrm{~kg} \cdot \mathrm{m} \cdot \mathrm{min}^{-1}$, accomplished by two subjects (CP and $R S)$. One of these subjects $(R S)$ exercised at $600 \mathrm{~kg} \cdot \mathrm{m}$ for 2 min but the $\mathrm{O}_{2}$ uptake was less than at $450 \mathrm{~kg} \cdot \mathrm{m} \cdot \mathrm{min}^{-1}$. Note that Table 7 shows all the data for the two subjects at $6,300 \mathrm{~m}$, breathing $14 \% \mathrm{O}_{2}$.

\section{$\mathrm{O}_{2}$ Uptake}

Sea Level. Table 2 shows that the mean $\mathrm{O}_{2}$ uptake (STPD) increased from about $1 \mathrm{l} / \mathrm{min}$ at a work rate of $300 \mathrm{~kg} \cdot \mathrm{m} \cdot \mathrm{min}^{-1}$ to $4.63 \mathrm{l} / \mathrm{min}$ for the highest work load of $2,400 \mathrm{~kg} \cdot \mathrm{m} \cdot \mathrm{min}^{-1}$ at sea level. In Fig. 2 the data have been expressed as $\mathrm{ml} \cdot \mathrm{min}^{-1} \cdot \mathrm{kg}$ body $\mathrm{wt}^{-1}$ and show a tight linear correlation between $\mathrm{O}_{2}$ uptake and work rate up to a work rate of $2,100 \mathrm{~kg} \cdot \mathrm{m} \cdot \mathrm{min}^{-1}$ where the $\mathrm{O}_{2}$ uptake was $57.7 \mathrm{I} \cdot \mathrm{min}^{-1} \cdot \mathrm{kg}^{-1}$ However, for the highest work rate of $2,400 \mathrm{~kg} \cdot \mathrm{m} \cdot \mathrm{min}^{-1}$ the $\mathrm{O}_{2}$ uptake falls below the straight line, indicating increased dependence on anaerobic metabolism. In general the relationship between $\mathrm{O}_{2}$ uptake and work level was very similar to that observed by Pugh et al. (21) and other previous investigators.

$6,300 \mathrm{~m}$ altitude, air breathing. It can be seen from Table 2 that at $6,300 \mathrm{~m}$ the measured $\mathrm{O}_{2}$ uptakes (expressed as $1 / \mathrm{min}$ ) fell slightly below the values obtained at sea level for the same work rate. However, as Table 1 shows, body weights at $6,300 \mathrm{~m}$ were lower than at sea level. Figure 2 shows that if $\mathrm{O}_{2}$ consumption is calculated in terms of $1 \cdot \mathrm{min}^{-1} \cdot \mathrm{kg}$ body $\mathrm{wt}^{-1}$, the relationship between $\mathrm{O}_{2}$ uptake and work rate for sea level and 6,300-m altitude became very close. Note that at the highest work level $\left(1,200 \mathrm{~kg} \cdot \mathrm{m} \cdot \mathrm{min}^{-1}\right)$, the $\mathrm{O}_{2}$ uptake departed from linearity.

The physiological significance of the agreement of the
$\mathrm{O}_{2}$ uptakes expressed as $\mathrm{ml} \cdot \mathrm{min}^{-1} \cdot \mathrm{kg}^{-1}$ is arguable. Certainly some of the weight loss at high altitude is the result of muscle wasting as evidenced by a marked reduction of girth of arms and legs. However, much of the weight loss is fat. Therefore it is questionable whether it is justifiable to attribute all of the lowering of maximal $\mathrm{O}_{2}$ uptake to loss of muscle mass.

$6,300 \mathrm{~m}$ altitude, low $\mathrm{O}_{2}$ breathing. Figure 2 shows that the two studies in which low $\mathrm{O}_{2}$ mixtures were inhaled generally showed the same relationship between $\mathrm{O}_{2}$ uptake $\left(\mathrm{ml} \cdot \mathrm{min}^{-1} \cdot \mathrm{kg}^{-1}\right)$ and work rate as was observed at sea level. However, the $300 \mathrm{~kg} \cdot \mathrm{m} \cdot \mathrm{min}^{-1}$ point for the $14 \% \mathrm{O}_{2}$ study shows an exceptionally high $\mathrm{O}_{2}$ uptake. A possible reason for this is the very high value of ventilation $(136 \mathrm{l} / \mathrm{min})$ and the associated $\mathrm{O}_{2}$ cost of breathing. This high value could certainly significantly raise $\mathrm{O}_{2}$ consumption $(16,22)$.

Note that when the subjects were breathing $14 \% \mathrm{O}_{2}$, the work rate of $450 \mathrm{~kg} \cdot \mathrm{m} \cdot \mathrm{min}^{-1}$ produced an $\mathrm{O}_{2}$ uptake no greater than that measured during the work rate of $300 \mathrm{~kg} \cdot \mathrm{m} \cdot \mathrm{min}^{-1}$. Clearly maximal aerobic power had been reached at the lower work level and the subjects were merely incurring a larger $\mathrm{O}_{2}$ debt at the higher level. One subject $(R S)$ actually worked at a rate of $600 \mathrm{~kg} \cdot \mathrm{m}$. $\min ^{-1}$ for 2 min but the measured $\mathrm{O}_{2}$ uptake was only $0.84 \mathrm{l} / \mathrm{min}$ and the respiratory exchange ratio $(\mathrm{R})$ value was 1.84 so this measurement was omitted from Table 2.

Our finding that $\mathrm{O}_{2}$ consumption for a given work rate is nearly independent of inspired $\mathrm{Po}_{2}$ confirms conclusions reached by earlier workers $(6,10,13,21)$ that the efficiency of muscular exercise is essentially independent of altitude. However, our studies extend the range of observations for maximal exercise to higher equivalent altitudes including the Everest summit.

\section{Ventilation}

When ventilation was corrected to STPD the values at $6,300 \mathrm{~m}$ were generally higher than those at sea level except at the lowest work rate of $300 \mathrm{~kg} \cdot \mathrm{m} \cdot \mathrm{min}^{-1}$. Considerable increases were seen in the studies in which low $\mathrm{O}_{2}$ mixtures were inhaled. Note, however, that the conversion of volumes to STPD at this altitude gives values that are different from those which would be obtained if the subjects were breathing $21 \% \mathrm{O}_{2}$ at the equivalent higher altitude $(8,848 \mathrm{~m}$, barometric pressure 250 Torr for $14 \% \mathrm{O}_{2}$ breathing).

Ventilation expressed as BTPS increased dramatically at the same work rate as the inspired $\mathrm{Po}_{2}$ was reduced. Note the extremely high level of $207 \mathrm{l} / \mathrm{min}$ recorded for a work rate of $1,200 \mathrm{~kg} \cdot \mathrm{m} \cdot \mathrm{min}^{-1}$ at $6,300 \mathrm{~m}$ when the subjects were breathing ambient air. These enormous levels of ventilations are helped by the fact that maximal voluntary ventilation increases at low barometric pressures because of the reduced work of breathing air of low density (7). The values of maximal exercise ventilation are discussed further below.

\section{Expired Gas Composition}

Table 2 shows that the $\mathrm{O}_{2}$ concentration of mixed expired gas generally increased as the work rate was 
raised at any given inspired $\mathrm{Po}_{2}$. However, there was no consistent change in the concentration of $\mathrm{CO}_{2}$ in mixed expired gas as the work level increased at any given inspired $\mathrm{PO}_{2}$, though it apparently fell at the highest work level at sea level. On the other hand there was a downward trend for expired $\mathrm{CO}_{2}$ concentration with increasing work rate for both subjects in the measurements made during $14 \% \mathrm{O}_{2}$ breathing.

\section{Respiratory Exchange Ratio}

The values of $R$ generally increased as work rate was raised at a particular inspired $\mathrm{Po}_{2}$. In addition, if a given work level is considered, the values of $\mathrm{R}$ increased as the inspired $\mathrm{PO}_{2}$ was reduced.

Note the remarkably high values of $\mathrm{R}$ at the low work levels when 16 and $14 \% \quad \mathrm{O}_{2}$ mixtures were inhaled. For example, when the inspired $\mathrm{O}_{2}$ was $16 \%$ and the work rate was only $300 \mathrm{~kg} \cdot \mathrm{m} \cdot \mathrm{min}^{-1}$, the value of $\mathrm{R}$ was 1.28 in spite of the fact that the six subjects could achieve double the work rate and almost double the $\mathrm{O}_{2}$ uptake. In an effort to reduce the level of $R$ to values more comparable with steady-state exercise, we arranged to have the subjects prebreathe low $\mathrm{O}_{2}$ mixtures for increasing periods of time up to $5 \mathrm{~min}$. However, values of $\mathrm{R}$ exceeding 1.0 were always seen. We were limited in the amount of time available for prebreathing low $\mathrm{O}_{2}$ mixtures because of the very large amounts of gas that had to be prepared. For example, note the extremely high ventilation (BTPS) of $78 \mathrm{l} / \mathrm{min}$ for the lowest work level of $150 \mathrm{~kg} \cdot \mathrm{m} \cdot \mathrm{min}$ when $14 \% \mathrm{O}_{2}$ was inspired.

\section{Alveolar Gas Partial Pressures}

The $\mathrm{O}_{2}$ and $\mathrm{CO}_{2}$ concentrations in mixed expired gas can be used to calculate the alveolar partial pressures if we assume values for the dead space-to-tidal volume ratio. This procedure can be justified during exercise when the dead space-to-tidal volume ratio lies within the range $0.2-0.1$ (1), because it can be shown that the resulting values are relatively insensitive to changes of the dead space-to-tidal volume ratio within this range. For example, in the measurements made at an altitude of $6,300 \mathrm{~m}$ during air or low $\mathrm{O}_{2}$ breathing, changing the dead space-to-tidal volume ratio from 0.2 to 0.1 alters the calculated alveolar $\mathrm{CO}_{2}$ partial pressure $\left(\mathrm{PCO}_{2}\right)$ by usually less than 1 Torr.

Table 3 shows the values for alveolar $\mathrm{PO}_{2}$ and $\mathrm{PCO}_{2}$ calculated in this way. Only the values for minimal and maximal work rates at any given altitude are shown. In the case of the measurements during $14 \% \mathrm{O}_{2}$ breathing at $6,300 \mathrm{~m}$ altitude, only the values obtained on one subject $(C P)$ are given. This is because of the marked differences between the two subjects (see Table 7) and the fact that the resting alveolar gas data on the summit were only obtained on this one subject. Note that the alveolar $\mathrm{Po}_{2}$ fell from 119 Torr during maximal exercise at sea level to a value of 37 Torr during maximal exercise when the inspired $\mathrm{Po}_{2}$ was 42.5 Torr. The corresponding values of alveolar $\mathrm{PCO}_{2}$ were 30 and 8 Torr.

Alveolar gas concentrations were also measured directly at altitudes of 8,050 and $8,848 \mathrm{~m}$ during the expedition using a special automatic alveolar gas sampler
TABLE 3. Alveolar $\mathrm{PO}_{2}$ and $\mathrm{PCO}_{2}$ during exercise

\begin{tabular}{|c|c|c|c|c|c|c|}
\hline \multirow{2}{*}{$\begin{array}{l}\text { Site } \\
\text { Inspired } \\
\text { Gas }\end{array}$} & \multirow{2}{*}{$\begin{array}{l}\text { Work Rate, } \\
\mathrm{kg} \cdot \mathrm{m} \cdot \mathrm{min}^{-1}\end{array}$} & \multirow{2}{*}{$\begin{array}{l}\text { Tidal } \\
\text { Volume, } \\
\text { liters }\end{array}$} & \multirow{2}{*}{$\begin{array}{c}\text { Calcu- } \\
\text { lated } \\
\text { Alveolar } \\
\mathrm{Po}_{2}, \\
\text { Torr }\end{array}$} & \multirow{2}{*}{$\begin{array}{c}\text { Calcu- } \\
\text { lated } \\
\text { Alveolar } \\
\mathrm{PcO}_{2}, \\
\text { Torr }\end{array}$} & \multicolumn{2}{|c|}{$\begin{array}{l}\text { Alveolar Gas at } \\
\text { Rest at Equiva- } \\
\text { lent Altitude* }\end{array}$} \\
\hline & & & & & $\begin{array}{l}\mathrm{Po}_{2}, \\
\text { Torr }\end{array}$ & $\begin{array}{l}\mathrm{PcO}_{2} \text {, } \\
\text { Torr }\end{array}$ \\
\hline $\begin{array}{l}\text { Sea level, } \\
\text { ambient } \\
\text { air }\end{array}$ & $\begin{array}{r}300 \\
2,400\end{array}$ & $\begin{array}{l}1.46 \\
3.08\end{array}$ & $\begin{array}{l}105 \ddagger \\
119 \S\end{array}$ & $\begin{array}{l}37 \\
30\end{array}$ & & \\
\hline $\begin{array}{l}6,300 \mathrm{~m}, \\
\text { ambient } \\
\text { air }\end{array}$ & $\begin{array}{r}300 \\
1,200\end{array}$ & $\begin{array}{l}1.87 \\
3.34\end{array}$ & $\begin{array}{l}48 \ddagger \\
52 \S\end{array}$ & $\begin{array}{l}15 \\
14\end{array}$ & & \\
\hline $\begin{array}{l}6,300 \mathrm{~m}, \\
16 \% \mathrm{O}_{2}\end{array}$ & $\begin{array}{l}300 \\
600\end{array}$ & $\begin{array}{l}2.19 \\
2.52\end{array}$ & $\begin{array}{l}38 \S \\
39 \S\end{array}$ & $\begin{array}{l}12 \\
12\end{array}$ & 36 & 11 \\
\hline $\begin{array}{r}6,300 \mathrm{~m}, \dagger \\
14 \% \mathrm{O}_{2} \\
\end{array}$ & $\begin{array}{l}150 \\
450\end{array}$ & $\begin{array}{l}0.94 \\
1.80\end{array}$ & $\begin{array}{l}35 \ddagger \\
37 \ddagger\end{array}$ & $\begin{array}{l}9 \\
8\end{array}$ & 38 & 7.5 \\
\hline
\end{tabular}

Alveolar $\mathrm{O}_{2}$ and $\mathrm{CO}_{2}$ partial pressures $\left(\mathrm{Po}_{2}\right.$ and $\mathrm{PcO}_{2}$, respectively) were calculated from mixed expired gas and compared with directly measured values at rest. $\quad{ }^{*}$ From Ref. 24 . † Values from subject $C P$ only because of the marked differences between the 2 subjects (see Table 7) and the fact that the directly measured values are also from subject $C P$ only. $\ddagger$ Dead space-to-tidal volume ratio assumed 0.2. $\$$ Dead space-to-tidal volume ratio assumed 0.1.

(24). The measurements were made during rest and the results are shown in the two right-hand columns of Table 3 . Recall that the inspired $\mathrm{PO}_{2}$ of 48.5 Torr measured during $16 \% \mathrm{O}_{2}$ breathing at $6,300 \mathrm{~m}$ was virtually the same inspired $\mathrm{Po}_{2}$ as at an altitude of $8,050 \mathrm{~m}$. Similarly the measurements made during $14 \% \mathrm{O}_{2}$ breathing at $6,300 \mathrm{~m}$ had an inspired $\mathrm{Po}_{2}$ almost the same as that on the Everest summit, altitude $8,848 \mathrm{~m}$. It can be seen that agreement for the equivalent altitude of $8,050 \mathrm{~m}$ was good with the $\mathrm{PCO}_{2}$, being within 1 Torr, while the exercise value of $\mathrm{Po}_{2}$ was 2-3 Torr higher, consistent with the higher value of $\mathrm{R}$. Agreement was also good for the equivalent altitude of $8,848 \mathrm{~m}$ (summit), the $\mathrm{PCO}_{2}$ values being within 1 Torr. The resting alveolar $\mathrm{Po}_{2}$ was actually slightly higher than the calculated exercise value, but the calculated $R$ from the alveolar gas samples was very high (1.49) for unexplained reasons (24).

\section{Arterial $\mathrm{O}_{2}$ Saturation}

Table 2 and Fig. 3 show the arterial $\mathrm{O}_{2}$ saturations as measured by ear oximeter. The oximeter was calibrated directly against arterial blood at $6,300 \mathrm{~m}$ as shown in Fig. 2, and the values for saturation as read off the calibration line are reported here. Note that at sea level the saturations at the beginning and end of exercise were generally in the range 97-98, though at the highest levels of exercise there was a tendency for the saturation to fall slightly.

At high altitude the $\mathrm{O}_{2}$ saturations were markedly reduced, the reductions being greater as the altitude increased. Note also that for a given inspired $\mathrm{Po}_{2}$, there was a reduction in $\mathrm{O}_{2}$ saturation (in either the first or last minute of exercise) at the higher work rates. This phenomenon has been shown by several other investigators at high altitude $(3,5,13,25)$. Note particularly that the fall in arterial $\mathrm{O}_{2}$ saturation occurred in the face of a rise in alveolar $\mathrm{Po}_{2}$ as shown in Table 3. The fall in 


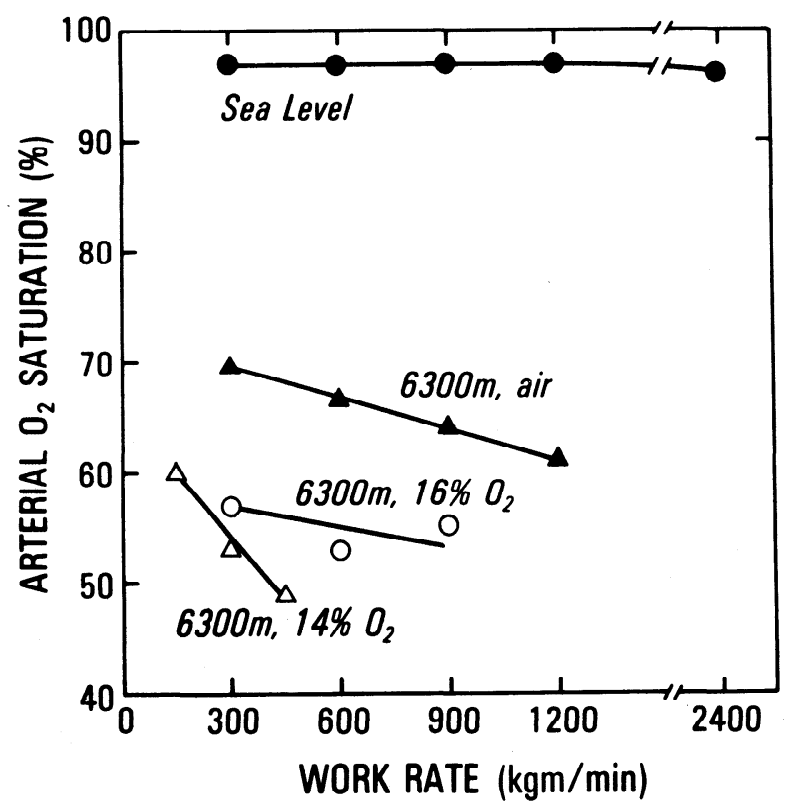

FIG. 3. Arterial $\mathrm{O}_{2}$ saturation against work rate for 4 conditions studied. Note steeply falling $\mathrm{O}_{2}$ saturation as work rate was increased when the inspired $\mathrm{PO}_{2}$ was very low. This can be explained by diffusion limitation of $\mathrm{O}_{2}$ transfer across blood gas barrier.

$\mathrm{O}_{2}$ saturation can be explained by diffusion limitation of $\mathrm{O}_{2}$ transfer under these conditions $(17,25,27)$. Indeed theoretical analyses show that even in a resting subject on the summit of Mt. Everest, marked diffusion limitation of $\mathrm{O}_{2}$ transfer must exist $(24,27)$.

Table 2 also shows that during the period of exercise at any particular work rate or inspired $\mathrm{Po}_{2}$ at high altitude there was a tendency for the $\mathrm{O}_{2}$ saturation to fall, especially at the highest work rates at the lowest values of inspired $\mathrm{Po}_{2}$. This can presumably be explained by depletion of $\mathrm{O}_{2}$ stores, resulting in a continued fall in the $\mathrm{PO}_{2}$ of mixed venous blood and therefore the $\mathrm{O}_{2}$ saturation of arterial blood.

It is possible to calculate alveolar-arterial $\mathrm{Po}_{2}$ differences from the available data. To derive the arterial $\mathrm{PO}_{2}$ from the measured arterial $\mathrm{O}_{2}$ saturation, we have used measurements of base excess and the $\mathrm{Po}_{2}$ at which hemoglobin is $50 \%$ saturated $\left(\mathrm{P}_{50}\right)$ made on samples of venous blood taken at the $6,300 \mathrm{~m}$ camp (Winslow, Samaja, and West; unpublished observations). The mean value for base excess was $-8.7 \mathrm{meq} / \mathrm{l}$ and that for $P_{50}$ at pH 7.4 and $\mathrm{PCO}_{2}=22.6$ was 29.8 Torr. Knowing the alveolar and therefore arterial $\mathrm{PCO}_{2}$, the arterial $\mathrm{O}_{2}$ saturation could then be calculated using the Kelman subroutines (see Ref. 28 for summary). We were unable to take into account the effect of any lactic acidosis; insofar as this reduced the $\mathrm{pH}$, it would reduce the alveolararterial $\mathrm{Po}_{2}$ differences. On the other hand the increases in lactate were small as shown below.

Table 4 shows that the alveolar-arterial $\mathrm{Po}_{2}$ differences were large at high altitude, being in the range of 8-15 Torr. These are very high in view of the fact that the values of $\mathrm{Po}_{2}$ are low on the $\mathrm{O}_{2}$ dissociation curve. These results are consistent with the known marked diffusion limitation of $\mathrm{O}_{2}$ transfer at high altitude, particularly during exercise. The values are generally consistent with the large alveolar-arterial $\mathrm{PO}_{2}$ differences calculated during maximal exercise at an altitude of 5,800 m (barometric pressure 380 Torr) on the 1960-1961 expedition (25). However, they are greater than those reported by Houston and Riley (13) in their low-pressure chamber experiment where the work levels were generally much lower. Note that any alveolar-arterial $\mathrm{Po}_{2}$ difference caused by ventilation-perfusion inequality is essentially negligible under these extremely hypoxic conditions (27).

\section{Blood Lactate Concentrations}

Table 5 shows the results in three subjects after maximal exercise at $6,300 \mathrm{~m}$ during air breathing. The maximal work rate of these subjects was $900 \mathrm{~kg} \cdot \mathrm{m} \cdot \mathrm{min}^{-1}$ and the mean $\mathrm{O}_{2}$ uptake was $1.75 \mathrm{l} / \mathrm{min}$. The mean value after exercise was $27.1 \mathrm{mg} / \mathrm{dl}$, the mean increase being $11.7 \mathrm{mg} / \mathrm{dl}$. These small increases in lactate concentration in spite of the severe hypoxemia shown in Table 4 are consistent with the results of Edwards (11). The reason for the low lactate levels is not understood but may be related to the relatively low work levels or perhaps the low buffering capacity of the bicarbonate-depleted blood.

\section{Heart Rate}

Table 2 shows that, as expected, heart rate increased with work rate at any inspired $\mathrm{Po}_{2}$ and that, for a given work rate, the heart rate was higher the lower the inspired $\mathrm{Po}_{2}$. Pugh (19) showed that at an altitude of 5,800 $\mathrm{m}$ (barometric pressure 380 Torr) acclimatized subjects had the same cardiac output- $\mathrm{O}_{2}$ uptake relationship as they do at sea level. If the same holds for the lower values of inspired $\mathrm{PO}_{2}$ studied here, the high heart rates imply substantial reductions in stroke volume.

TABLE 4. Calculated alveolar-arterial $\bar{P}_{2}$ differences at high altitudes

\begin{tabular}{lcccc}
\hline $\begin{array}{c}\text { Site, } \\
\text { Inspired } \\
\text { Gas }\end{array}$ & $\begin{array}{c}\text { Work Rate, } \\
\mathbf{k g} \cdot \mathbf{m} \cdot \mathbf{m i n}\end{array}$ & $\begin{array}{c}\text { Alveolar } \\
\mathrm{Po}_{2}, \\
\text { Torr }\end{array}$ & $\begin{array}{c}\text { Arterial } \\
\mathrm{Po}_{2}{ }^{*} \\
\text { Torr }\end{array}$ & $\begin{array}{c}\text { Alveolar- } \\
\text { Arterial } \\
\mathbf{P o}_{2} \text { Diff, } \\
\text { Torr }\end{array}$ \\
\hline $\begin{array}{c}6,300 \mathrm{~m}, \\
\text { ambient } \\
\text { air }\end{array}$ & 300 & 48 & 36 & 12 \\
& 1,200 & 52 & 31 & 21 \\
$6,300 \mathrm{~m}$, & 300 & 38 & 28 & 10 \\
$16 \% \mathrm{O}_{2}$ & 600 & 39 & 27 & 12 \\
& 150 & 35 & 27 & 8 \\
$6,300 \mathrm{~m}$, & 450 & 37 & 22 & 15 \\
$14 \% \mathrm{O}_{2}$ & & & & \\
\hline $\mathrm{Po}_{2}, \mathrm{O}_{2}$ partial pressure; $\mathrm{PcO}_{2}, \mathrm{CO}_{2}$ partial pressure. & ${ }^{*}$ Calculated
\end{tabular}
from the arterial $\mathrm{O}_{2}$ saturation, $\mathrm{pH}, \mathrm{PCO}_{2}$, and $\mathrm{P}_{50}$.

TABLE 5. Blood lactate concentrations before and after maximal exercise at 6,300 $\mathrm{m}$

\begin{tabular}{lccccc}
\hline Subj & $\begin{array}{c}\text { Hemoglobin, } \\
\text { g/dl }\end{array}$ & $\begin{array}{c}\text { Hemato- } \\
\text { crit, } \\
\%\end{array}$ & $\begin{array}{c}\text { Work Level, } \\
\text { kg·m·min }\end{array}$ & \multicolumn{2}{c}{ Lactate, mg/dl } \\
\hline$F S$ & 18.7 & 54 & 900 & Before & After \\
$P H$ & 20.2 & 54 & 900 & 21.5 & 28.6 \\
$J M$ & 17.4 & 50 & 900 & 11.0 & 23.1 \\
& & & & &
\end{tabular}


TABLE 6. Summary of results of maximal exercise at each value of inspired $\mathrm{PO}_{2}$

\begin{tabular}{|c|c|c|c|c|c|c|c|c|}
\hline $\begin{array}{c}\text { Site, } \\
\text { Inspired Gas }\end{array}$ & $\begin{array}{l}\text { PB, } \\
\text { Torr }\end{array}$ & $\begin{array}{c}\text { Equivalent PB } \\
\text { for Air } \\
\text { Breathing, } \\
\text { Torr }\end{array}$ & $\begin{array}{c}\text { Equivalent } \\
\text { Altitude } \\
\text { for Air } \\
\text { Breathing, } \\
\text { m }\end{array}$ & $\begin{array}{c}\text { Max Work Rate, } \\
\mathrm{kg} \cdot \mathrm{m} \cdot \mathrm{min}^{-1}\end{array}$ & $\begin{array}{l}\dot{\mathrm{V}} \mathbf{o}_{\text {max }}, \\
\mathrm{l} / \mathrm{min}\end{array}$ & $\begin{array}{c}\dot{\mathrm{V} \mathbf{O}_{2 \max },} \\
\mathrm{ml} \cdot \mathrm{min}^{-1} \cdot \mathrm{kg}^{-1}\end{array}$ & $\begin{array}{c}\dot{\mathrm{V}} \mathrm{E}_{\max }, \\
\text { BTPS } 1 / \min \end{array}$ & $\begin{array}{c}\text { Max Heart } \\
\text { Rate, } \\
\text { beats } / \mathrm{min}^{-1}\end{array}$ \\
\hline Sea level, air & 750 & 750 & SL & 2,400 & 4.63 & 61.3 & 160 & 170 \\
\hline $6,300 \mathrm{~m}$, air & 351.3 & 351 & 6,300 & 1,200 & 2.31 & 32.4 & 207 & 146 \\
\hline $6,300 \mathrm{~m}, 16 \% \mathrm{O}_{2}$ & 350.0 & 280 & 8,050 & 600 & 1.45 & 20.6 & 159 & 128 \\
\hline $6,300 \mathrm{~m}, 14 \% \mathrm{O}_{2}$ & 350.5 & 250 & 8,848 & $300-450^{*}$ & 1.07 & 15.3 & 162 & 135 \\
\hline
\end{tabular}

$\mathrm{Po}_{2}, \mathrm{O}_{2}$ partial pressure; $\mathrm{PB}$, barometric pressure; $\dot{\mathrm{V}}_{2 \max }$, maximal $\mathrm{O}_{2}$ uptake; $\dot{\mathrm{V}} \mathrm{E}_{\max }$, maximal exercise ventilation; SL, sea level. * Although both subjects were able to work at $450 \mathrm{~kg} \cdot \mathrm{m} \cdot \mathrm{min}^{-1}$ for $3 \mathrm{~min}$ (one subject at $600 \mathrm{~kg} \cdot \mathrm{m} \cdot \mathrm{min}{ }^{-1}$ for $2 \mathrm{~min}$ ), the values of the Vo $0_{2 \max }$ were slightly lower than for $300 \mathrm{~kg} \cdot \mathrm{m} \cdot \mathrm{min}$ (see Fig. 3 and Table 2).

\section{Maximal Exercise in Relation to Inspired $\mathrm{PO}_{2}$}

Table 6 summarizes the data.

$\mathrm{O}_{2}$ uptake. It can be seen that maximal $\mathrm{O}_{2}$ uptake declined dramatically at the lowest values of inspired $\mathrm{Po}_{2}$, i.e., at the highest equivalent altitudes. At sea level the mean value in five subjects was $4.63 \mathrm{l} / \mathrm{min}$ or 61.3 $\mathrm{ml} \cdot \mathrm{min}^{-1} \cdot \mathrm{kg}^{-1}$. When the inspired $\mathrm{Po}_{2}$ was reduced to 42.5 Torr, equivalent to an altitude of $8,848 \mathrm{~m}$, the mean maximal $\mathrm{O}_{2}$ uptake in two subjects was $1.07 \mathrm{l} / \mathrm{min}$ or $15.3 \mathrm{ml} \cdot \mathrm{min}^{-1} \cdot \mathrm{kg}^{-1}$.

Figure 4 shows a plot of maximal $\mathrm{O}_{2}$ uptake $\left(\mathrm{ml} \cdot \mathrm{min}^{-1}\right.$. $\mathrm{kg}^{-1}$ ) against inspired $\mathrm{Po}_{2}$. The figure also shows data reported by Pugh et al. (21) based on measurements made during the Himalayan Scientific and Mountaineering Expedition of 1960-1961 and additional measurements at lower altitudes on Mt. Everest (see Fig. 2, Ref. 21).

Our data differ from those of Pugh et al. (21) in several ways. First note that the maximal $\mathrm{O}_{2}$ uptake at sea level was substantially higher (24\%) than in the subjects of the previous study. As indicated earlier under METHODS, many of our subjects were marathon runners, and in fact all the five subjects whose results gave the point at the top of Fig. 4 fell into this category. Consistent with (though not necessarily caused by) this, the maximal $\mathrm{O}_{2}$ uptakes at values of inspired $\mathrm{PO}_{2}$ of $63.7,48.5$, and 42.5 Torr were all above those of the previous study. It might be added that the regression line (least-squares fit) of the previous study is considerably influenced by the lowest point, which was measured under demanding conditions in a tent at an altitude of 7,440 $\mathrm{m}$ on the Makalu Col. In addition, one of the two subjects studied developed frank pneumonia 2 days later and was probably not very fit at the time of the exercise study.

Figure 4 shows that the two lines are not widely separated in the lower region, but because the slope is so steep, a small leftward displacement of the curve results in a large increase in maximal $\mathrm{O}_{2}$ uptake in the present study. These measurements clearly help to explain how climbers can reach the summit of Mt. Everest without supplementary $\mathrm{O}_{2}$. Such a feat was very difficult to understand on the basis of the previous measurements of maximal $\mathrm{O}_{2}$ uptake at extreme altitudes (27). Nevertheless with a maximal $\mathrm{O}_{2}$ uptake of only about $1 \mathrm{l} / \mathrm{min}$, the climbers clearly have very little in reserve.

Ventilation. Table 6 and Fig. 5 show that maximal total ventilation, expressed as BTPS, increased with alti-

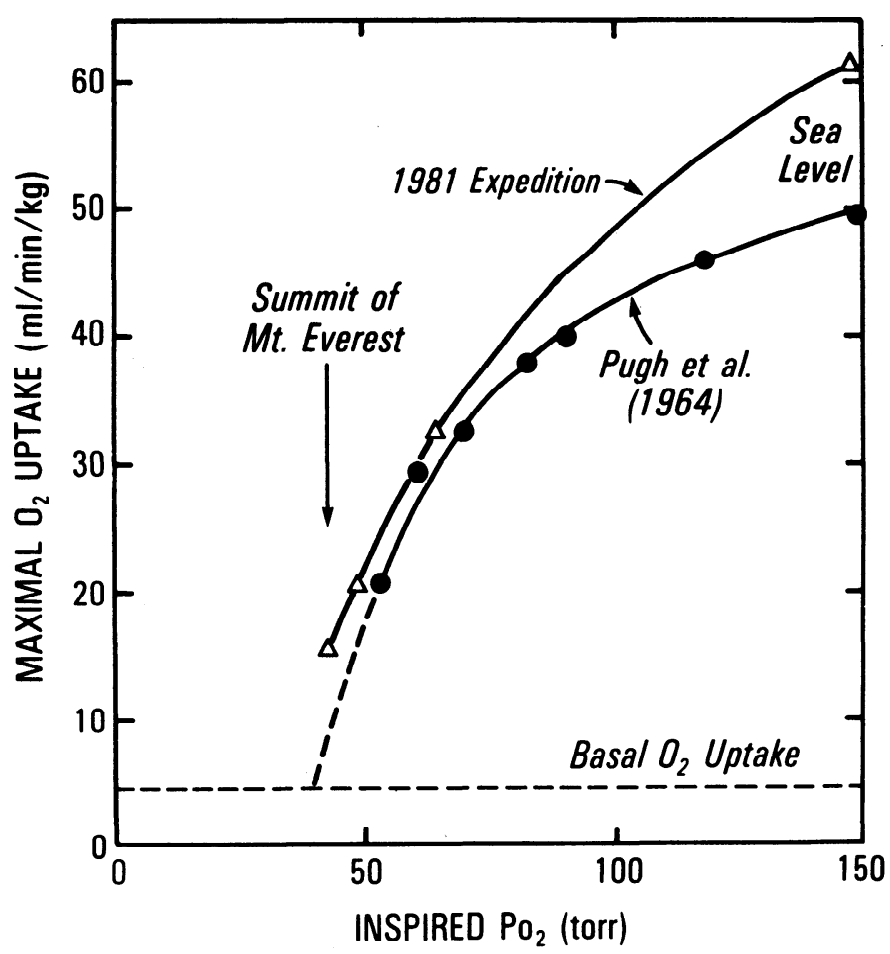

FIG. 4. Maximal $\mathrm{O}_{2}$ uptake against inspired $\mathrm{Po}_{2}$. The present data (triangles) are contrasted with measurements (circles) made previously by Pugh et al. (21). Note that although curve derived from data in present study is only slightly shifted to left, because of steepness of slope, gain in maximal $\mathrm{O}_{2}$ uptake at extreme altitudes is substantial.

tude up to a certain point and then decreased again. At first sight this is paradoxical, since, as Table 2 shows, for any given work rate the ventilation continued to increase as inspired $\mathrm{Po}_{2}$ was reduced. The reason for the maximum is that at the highest altitudes the work rates are so low that although ventilation in relation to work rate is high, the absolute value of ventilation is reduced. Note that the broken line showing maximal ventilation in Fig. 5 is based on only four points and is therefore very approximate. It is not possible to incorporate the measurements of maximal ventilation reported by Pugh et al. (21) because the ventilations in that study were generally considerably lower, consistent with the lower maximal work rate.s. Note that although total ventilation decreases at the lowest $\mathrm{Po}_{2}$ values, respiratory rate continues to increase resulting in very shallow breathing.

Heart rate. Table 6 and Fig. 5 show that maximal heart rate also decreased with inspired $\mathrm{Po}_{2}$. Again there is 
something of a paradox here because for a given work rate heart rate increases as inspired $\mathrm{Po}_{2}$ is reduced. The decline in maximal heart rate can be explained by the fall in maximal work rate.

The finding that maximal ventilation and heart rate were reduced at great altitudes confirms earlier observations of Pugh et al. (21). They noted that maximal ventilation fell from a peak of about $170 \mathrm{l} / \mathrm{min}$ BTPS at an altitude of $6,400 \mathrm{~m}$ (barometric pressure 340 Torr) to about $120 \mathrm{l} / \mathrm{min}$ at 7,440 (barometric pressure 300 Torr). Maximal heart rate fell consistently with increase in altitude as in the present study as also observed by others $(5,6,21)$.

Studies during climbing. Ventilation and heart rate were also measured on two subjects $(C P$ and $P H)$ when they were climbing at their maximal rate above Camp 5 en route to the summit on October 24. For these studies the subjects took off their oxygen masks and breathed

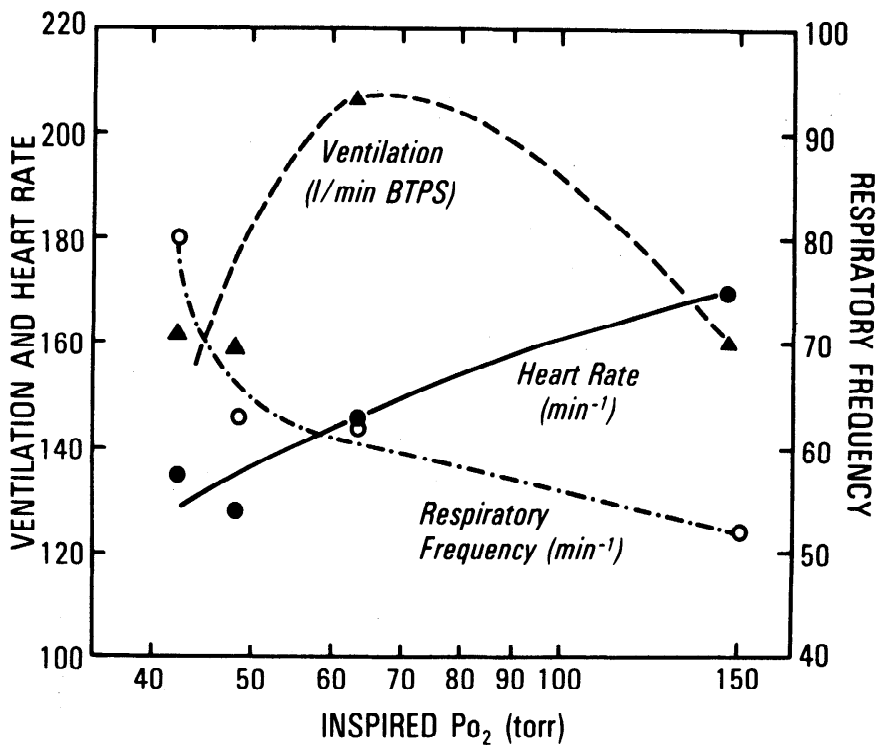

FIG. 5. Maximal ventilation (BTPS), maximal respiratory frequency, and maximal heart rate against inspired $\mathrm{Po}_{2}$ on a log scale. This scale was chosen because otherwise the high-altitude points fall very close together. Note that both maximal ventilation and heart rate fall at extreme altitudes because work levels become so restricted. However, respiratory frequency continues to increase. air. The best data were obtained on subject $C P$, who was at an altitude of $8,300 \mathrm{~m}$, as judged from the barometric pressure of 271.4 Torr which he read from his portable barometer. He climbed for 6 min $45 \mathrm{~s}$, while measuring his ventilation with the turbine flow meter. During the middle 4 min his mean ventilation was $107.0 \pm 6.3$ (SD) l/min BTPS, though it was slightly less for the first and last minutes. The mean respiratory frequency for the middle 4 min was $86 \pm 2.8$ (SD) breaths $/ \mathrm{min}$, giving a mean tidal volume of 1.26 liters. He was therefore breathing rapidly and shallowly.

These values are considerably lower than those obtained during his 3-min measurement of maximal $\mathrm{O}_{2}$ uptake during $14 \% \mathrm{O}_{2}$ breathing at $6,300 \mathrm{~m}$ (Table 7). On that occasion the ventilation was $166 \mathrm{l} / \mathrm{min}$ BTPS, frequency 100 and tidal volume 1.66 liters (note the rapid shallow pattern again). The lower values are consistent with the fact that climbers in the field do not reach the highest work levels that can be obtained in the laboratory. In fact Pugh (20) showed that climbers typically select an $\mathrm{O}_{2}$ uptake of one-half to three-fourths of their maximum for normal climbing at altitudes up to 6,000 $\mathrm{m}$.

The mean heart rate during the last 5 min of free climbing was $134 \pm 2.7$ (SD) beats/min, which was virtually the same as that measured during maximal exercise during $14 \% \mathrm{O}_{2}$ breathing at $6,300 \mathrm{~m}$, where the value was $132 / \mathrm{min}$.

The data obtained on the other subject $(P H)$ were less satisfactory. He did not have a barometer but estimated his altitude to be $8,500 \mathrm{~m}$, where the barometric pressure is 265 Torr (26). The duration of exercise was only $1 \mathrm{~min}$ $36 \mathrm{~s}$, which is too shcrt for steady-state data. Over that period the average values for breathing frequency and heart rate were 50 breaths/min and 144 beats $/ \mathrm{min}$, respectively. A satisfactory measurement of ventilation volume was not obtained.

\section{Differences Between Subjects}

The pooled data of Table 2 do not show the differences between subjects at any given inspired $\mathrm{Po}_{2}$. In some instances these were considerable. For example, some

TABLE 7. Comparison of two subjects exercising at $6,300 \mathrm{~m}$ while breathing $14 \% \mathrm{O}_{2}$

\begin{tabular}{|c|c|c|c|c|c|c|c|c|}
\hline \multicolumn{2}{|l|}{ Variable } & \multicolumn{3}{|c|}{ Subj $C P$} & \multicolumn{4}{|c|}{ Subj RS } \\
\hline Barometer pressure, Torr & & 349.9 & & & 351 & & & \\
\hline Work rate, $\mathrm{kg} \cdot \mathrm{m} \cdot \mathrm{min}^{-1}$ & & 150 & 300 & 450 & 150 & 300 & 450 & 600 \\
\hline Duration, $\min$ & & 5 & 3 & 3 & 3 & 3 & 3 & 2 \\
\hline Ventilation, $1 / \min$ BTPS & & 78.8 & 165.9 & 179.5 & 78.0 & 106.0 & 144.2 & 136.6 \\
\hline Respiration rate, breaths $/ \mathrm{min}$ & & 84 & 100 & 100 & 54 & 54 & 52 & 60 \\
\hline Heart rate, beats/min & & 96 & 132 & 120 & 132 & 138 & 138 & 144 \\
\hline Expired $\mathrm{O}_{2}, \%$ & & 11.89 & 12.10 & 12.45 & 10.90 & 11.07 & 10.72 & 11.07 \\
\hline Expired $\mathrm{CO}_{2}, \%$ & & 2.32 & 2.09 & 2.09 & 4.00 & 3.86 & 3.73 & 3.18 \\
\hline $\mathrm{O}_{2}$ uptake, $\mathrm{l} / \mathrm{min}$ & & 0.57 & 1.09 & 0.92 & 0.81 & 1.04 & 1.05 & 0.84 \\
\hline Resp exchange ratio & & 1.12 & 1.12 & 1.43 & 1.35 & 1.39 & 1.80 & 1.82 \\
\hline Oximeter reading, $\%$ for each $\min$ & 1 & 68 & 54 & 55 & 39 & 25 & 20 & 13 \\
\hline & 2 & 64 & 60 & & 37 & 25 & 17 & 11 \\
\hline & 3 & 64 & 62 & 45 & 33 & 23 & 17 & \\
\hline & 4 & 62 & & & & & & \\
\hline Alveolar $\mathrm{PCO}_{2}$, Torr* & 5 & $\begin{array}{l}60 \\
8-9\end{array}$ & $7-8$ & $7-8$ & $14-15$ & $13-15$ & $13-14$ & $11-12$ \\
\hline
\end{tabular}

Comparison between 2 subjects was made at a partial pressure of inspired $\mathrm{O}_{2}$ value of 42.5 , equivalent to the Everest summit. ${ }^{*}$ Calculated for a range of dead space-to-tidal volume ratio from 0.1 to 0.2 . 
subjects developed a much higher exercise ventilation than others, with the result that they had higher values for expired $\mathrm{O}_{2}$ concentration and arterial $\mathrm{O}_{2}$ saturation and lower values of expired $\mathrm{CO}_{2}$ concentration. Table 7 shows an example of marked differences in ventilatory responses in the two subjects $(C P$ and $R S)$ studied while inhaling $14 \% \mathrm{O}_{2}$ at $6,300 \mathrm{~m}$. The data are given for all work levels but note particularly the results for the rate of $300 \mathrm{~kg} \cdot \mathrm{m} \cdot \mathrm{min}^{-1}$. This gave the highest $\mathrm{O}_{2}$ uptakes. Although both subjects were able to sustain $450 \mathrm{~kg} \cdot \mathrm{m}$. $\min ^{-1}$ for $3 \mathrm{~min}$, the measured $\mathrm{O}_{2}$ uptakes did not increase.

Table 7 shows that both subjects were able to consume just over $1 \mathrm{l} / \mathrm{min}$ of $\mathrm{O}_{2}$ at a work rate of $300 \mathrm{~kg} \cdot \mathrm{m} \cdot \mathrm{min}^{-1}$. However, note the striking differences in ventilation; the value for subject $C P$ was $166 \mathrm{l} / \mathrm{min}$, whereas that for subject $R S$ was only $106 \mathrm{l} / \mathrm{min}$. Consistent with this, the alveolar $\mathrm{PCO}_{2}$ calculated assuming a dead space-to-tidal volume ratio in the range $0.1-0.2$ was 7-8 Torr for subject $C P$ but 13-15 Torr for subject $R S$. As pointed out earlier this value of $\mathrm{PCO}_{2}$ was the same as that found for subject $C P$ on the summit of Mt. Everest when he collected alveolar gas samples using the automatic sampler (24).

Figure 6 shows the ventilations and ear oximeter readings for all the work rates at $6,300 \mathrm{~m}$ during $14 \% \mathrm{O}_{2}$ breathing. In this figure the oximeter readings have not been converted to $\mathrm{O}_{2}$ saturation because the calibration data (Fig. 1) do not extend low enough. Note that the lower ventilations of subject $R S$ were associated with lower oximeter readings. These were remarkably low at the high work levels; indeed during the $600 \mathrm{~kg} \cdot \mathrm{m} \cdot \mathrm{min}^{-1}$ run, the reading fell to less than $10 \%$ at one point.

However, the low $\mathrm{O}_{2}$ saturations in subject $R S$ cannot be wholly accounted for by his relatively low ventilation. This is clearly seen at the work rate of $150 \mathrm{~kg} \cdot \mathrm{m} \cdot \mathrm{min}$, where although the ventilations were the same, the $\mathrm{O}_{2}$ saturation of subject $R S$ was much lower. It is true that his $\mathrm{O}_{2}$ uptake was slightly higher $(0.81$ compared with $0.57 \mathrm{l} / \mathrm{min}$ for subj $C P$ ) and his alveolar $\mathrm{Po}_{2}$ (calculated from and assumed dead space-to-tidal volume ratio) was 26 as opposed to 29 Torr for subject $C P$. However, this small difference cannot explain the much lower oximeter reading. Presumably the explanation lies in differences in the diffusing capacity for $\mathrm{O}_{2}$ though we have no data on this point.

The magnitudes of the exercise ventilations correlated strongly with the hypoxic ventilatory responses measured both at sea level and in the Base Camp laboratory (alt 5,400 m, barometric pressure 400 Torr). These studies, which clearly have an important bearing on exercise tolerance at extreme altitudes, will be reported separately.

\section{Comparison of Two Subjects Studied 20 Years Apart}

Two subjects of the present expedition ( $J M$ and $J W$ ) were members of the Himalayan Scientific and Mountaineering Expedition 1960-1961, and it is of interest to compare their exercise responses both at sea level and high altitude $20 \mathrm{yr}$ later. Table 8 shows that the altitudes at which exercise was studied were slightly different; in 1961 the barometric pressure was 344 Torr (alt 6,400 m),

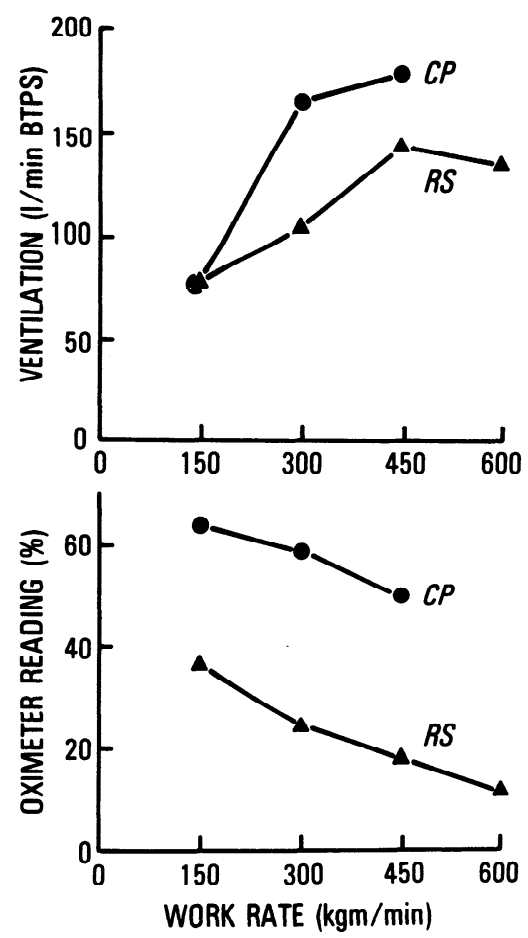

FIG. 6. Ventilations and ear oximeter readings for 2 subjects who exercised at $6,300 \mathrm{~m}$ while breathing $14 \% \mathrm{O}_{2}$. Inspired $\mathrm{Po}_{2}$ of 42.5 Torr was equivalent to that at summit of Mt. Everest. Note much higher ventilations and oximeter readings for subject $C P$.

whereas on the present expedition the barometric pressure was 351 Torr (alt 6,300 m). Subject $J W$ actually performed a measurement of maximal exercise at an altitude of 7,440 $\mathrm{m}$ (barometric pressure 300 Torr), in 1961 but there was no comparable study on the present expedition.

It can be seen that there was only a moderate deterioration of performance over the $20 \mathrm{yr}$ period. The $\mathrm{O}_{2}$ uptakes $(1 / \mathrm{min})$ fell by only 6 and $7 \%$ at sea level and by only $5 \%$ at high altitude for subject $J W$, though the figure was $20 \%$ for subject JM. When the $\mathrm{O}_{2}$ uptakes were expressed as $\mathrm{ml} \cdot \mathrm{min}^{-1} \cdot \mathrm{kg}^{-1}$, the decrements were slightly greater, being 7 and $12 \%$ at sea level and 25 and $13 \%$ at high altitude for subjects $J M$ and $J W$, respectively. Maximal heart rate showed a consistent downward trend, but maximal ventilation was variable. The results are in line with the studies by Dill et al. (9), who found that the effects of aging on human performance at high altitude show great variability between individuals but that changes up to the age of about $50 \mathrm{yr}$ may be very small.

\section{DISCUSSION}

\section{Limitations of the Low $\mathrm{O}_{2}$ Inhalation Studies}

The experiments in which subjects inhaled $\mathrm{O}_{2}$ concentrations of 16 and $14 \%$ while performing maximal exercise at an altitude of $6,300 \mathrm{~m}$ allowed us to obtain information on factors limiting performance at extreme altitudes up to the summit of Mt. Everest. These subjects were well acclimatized to $6,300 \mathrm{~m}$ with a partially compensated respiratory alkalosis, the mean base excess being $-9.4 \mathrm{meq} / \mathrm{l}$ (Winslow, Samaja, and West; unpub- 
TABLE 8. Comparison of two subjects studied 20 yr apart

\begin{tabular}{|c|c|c|c|c|c|c|c|c|c|c|c|c|}
\hline \multirow{3}{*}{ Variable } & \multicolumn{6}{|c|}{ Subj JM } & \multicolumn{6}{|c|}{ Subj JW } \\
\hline & \multicolumn{2}{|c|}{ Sea level } & \multirow{2}{*}{$\begin{array}{c}\% \\
\text { Fall }\end{array}$} & \multicolumn{2}{|c|}{ High altitude } & \multirow{2}{*}{$\begin{array}{c}\% \\
\text { Fall }\end{array}$} & \multicolumn{2}{|c|}{ Sea level } & \multirow{2}{*}{$\begin{array}{c}\% \\
\text { Fall }\end{array}$} & \multicolumn{2}{|c|}{ High altitude } & \multirow{2}{*}{$\begin{array}{c}\% \\
\text { Fall }\end{array}$} \\
\hline & 1961 & 1981 & & 1961 & 1981 & & 1961 & 1981 & & 1961 & 1981 & \\
\hline $\begin{array}{l}\text { Barometric pressure, } \\
\text { Torr }\end{array}$ & 750 & 750 & & 344 & 351 & & 750 & 750 & & 344 & 351 & \\
\hline Age, yr & 30 & 50 & & 30 & 51 & & 32 & 52 & & 32 & 52 & \\
\hline Weight, kg & 68.5 & 69.2 & & 59.9 & 64.2 & & 73.9 & 78.8 & & 64.0 & 70.1 & \\
\hline $\begin{array}{l}\text { Max work rate, } \mathrm{kg} \text {. } \\
\mathrm{m} \cdot \mathrm{min}^{-1}\end{array}$ & 1,860 & 1,500 & & 900 & 900 & & 1,950 & 1,800 & & 1,050 & 900 & \\
\hline $\mathrm{O}_{2}$ uptake, $1 / \mathrm{min}$ & 3.65 & 3.43 & 6 & 1.90 & 1.52 & 20 & 3.93 & 3.67 & 7 & 2.11 & 2.01 & 5 \\
\hline $\begin{array}{l}\mathrm{O}_{2} \text { uptake, } \mathrm{ml} \text {. } \\
\min ^{-1} \cdot \mathrm{kg}^{-1}\end{array}$ & 53.3 & 49.6 & 7 & 31.7 & 23.7 & 25 & 53.2 & 46.2 & 12 & 33.0 & 28.7 & 13 \\
\hline Ventilation, $1 /$ & 146.5 & 105.8 & & 149.4 & 176.9 & & 153.9 & 140.1 & & 202.3 & 178.1 & \\
\hline Heart rate, min & 197 & 182 & & & 120 & & 177 & 162 & & 133 & 120 & \\
\hline
\end{tabular}

lished observations). The subjects had been at altitudes of $5,400 \mathrm{~m}$ or higher for about $5 \mathrm{wk}$ before the studies were made.

However, it should not necessarily be assumed that a subject who is well acclimatized to an altitude of 6,300 $\mathrm{m}$ and who breathes $14 \% \mathrm{O}_{2}$ at that altitude is in the same situation as a climber who reaches the summit of Mt. Everest. We might expect additional acclimatization changes to occur during the 3-5 days that a climber would normally take to go from Camp 2 (alt 6,300 m) to the summit. On the other hand there is some evidence that these additional changes were small and that therefore the low $\mathrm{O}_{2}$ inhalation experiments did nearly reproduce the conditions at extreme altitudes. For example, it was pointed out during the discussion of Tables 3 and 7 that the alveolar $\mathrm{PCO}_{2}$ of 7-8 Torr of subject $C P$ when he achieved his maximal $\mathrm{O}_{2}$ uptake breathing $14 \% \mathrm{O}_{2}$ at $6,300 \mathrm{~m}$ was the same as that measured from alveolar gas samples taken by him on the summit 6 days later (24). This suggests that his exercise ventilation was not inhibited by a lack of acclimatization to altitudes above $6,300 \mathrm{~m}$.

Another line of evidence also indicates that subject $C P$ was as well acclimatized to extreme altitudes when the low $\mathrm{O}_{2}$ mixture experiment was performed at $6,300 \mathrm{~m}$ as he was on the summit 6 days later. On the morning following his successful summit climb, venous blood was taken and brought down to Camp $2(6,300 \mathrm{~m})$ for tonometry and analysis. This sample showed a base excess of $-5.9 \mathrm{meq} / \mathrm{l}(24)$. This was higher (less negative) than the average base excess of $-8.7 \mathrm{meq} / \mathrm{l}$ of the expedition members living at 6,300 m (Winslow, Samaja, and West; unpublished observations). Indeed a sample of blood taken from subject $C P$ at $6,300 \mathrm{~m} 16$ days prior to the experiment of Table 7 gave a base excess of $-9.8 \mathrm{meq} / \mathrm{l}$. Thus these data certainly do not suggest that subject $C P$ reduced his base excess more as a result of his excursion to the summit than was the case at the time of the experiment at $6,300 \mathrm{~m}$ with $14 \% \mathrm{O}_{2}$ inhalation. Naturally it is possible that other features of acclimatization such as the cerebrospinal fluid $\mathrm{pH}$ were not comparable on the two occasions, but we have no data in this area.

During the experiments with low inspired $\mathrm{O}_{2}$ mixtures, some concern was expressed about possible dangers of the very severe hypoxemia. As an example, the oximeter reading on subject $R S$ during 2 min of exercise at a work rate of $600 \mathrm{~kg} \cdot \mathrm{m} \cdot \mathrm{min}^{-1}$ while breathing $14 \% \mathrm{O}_{2}$ fell to less than $10 \%$. Since calibration points were not obtained as low as this the actual arterial $\mathrm{O}_{2}$ saturation is not known but it was certainly extremely low. However, none of the subjects who exercised while breathing low $\mathrm{O}_{2}$ mixtures (or ambient air) complained of dizziness; the overwhelming sensations were fatigue and breathlessness. Our justification for carrying out these studies was that all the subjects planned to go to the South Col (equivalent to $16 \% \mathrm{O}_{2}$ breathing) and hoped to go to the summit (equivalent to $14 \% \mathrm{O}_{2}$ breathing). Thus the conditions that we simulated were no different from those that they planned to encounter in the next few days in much more hazardous circumstances.

\section{Maximal $\mathrm{O}_{2}$ Uptake on the Summit of Mt. Everest}

The data presented here together with measurements of alveolar gas concentrations taken on the summit (24) improve our understanding of how it is possible for man to climb to the summit of Mt. Everest without supplementary $\mathrm{O}_{2}$. Previous data (21) as shown in Fig. 4 suggested that the available $\mathrm{O}_{2}$ on the summit was barely sufficient to satisfy metabolic demands. An extensive theoretical analysis (27) suggested that reaching the summit was probably feasible but that the maximal $\mathrm{O}_{2}$ uptake there would be less than $700 \mathrm{ml} / \mathrm{min}$.

The present study showed that it was possible for two well-acclimatized subjects to manage an $\mathrm{O}_{2}$ consumption of over $1 \mathrm{l} / \mathrm{min}$ when the inspired $\mathrm{Po}_{2}$ was 43 Torr, as it is on the summit. Although this is clearly very limiting, it is apparently sufficient to explain how Messner and Habeler reached the summit of Mt. Everest without supplementary $\mathrm{O}_{2}$. Messner (15) stated that the last 100 $\mathrm{m}$ of height took more than an hour to climb. If we assume that they climbed at a rate of $2 \mathrm{~m} / \mathrm{min}$ and that the weight of a climber plus equipment was $100 \mathrm{~kg}$, the average work rate was $200 \mathrm{~kg} \cdot \mathrm{m} \cdot \mathrm{min}^{-1}$. This is therefore appreciably less than the $300 \mathrm{~kg} \cdot \mathrm{m} \cdot \mathrm{min}^{-1}$ corresponding to the maximal $\mathrm{O}_{2}$ uptake of $1.07 \mathrm{l} / \mathrm{min}$ measured on the two subjects inspiring a $\mathrm{PO}_{2}$ of 42.5 Torr. In fact both subjects were able to sustain a work rate of $450 \mathrm{~kg} \cdot \mathrm{m}$. $\min ^{-1}$ for $3 \mathrm{~min}$, though there was no increase in $\mathrm{O}_{2}$ uptake, indicating that they were merely incurring a 
larger $\mathrm{O}_{2}$ debt.

The disparity between our results and those of the earlier experimental study (21) is partly explained by the fact that our subjects were considerably fitter and had a considerably higher maximal $\mathrm{O}_{2}$ uptake at sea level. In addition, the improved performance of our subjects over that predicted from the theoretical analysis (27) probably stems from three main factors. First, the barometric pressure on the summit is slightly higher than we had predicted (26). Second, the base excess of a subject on the summit is substantially higher (less negative) than we had predicted. It can be shown that the resulting alkalosis enhances the loading of $\mathrm{O}_{2}$ in the pulmonary capillaries under these very hypoxic conditions and ultimately results in a higher tissue $\mathrm{Po}_{2}$ (4). Third, the very low $\mathrm{PCO}_{2}$ brought about by extreme hyperventilation helps to maintain the alveolar $\mathrm{PO}_{2}$ in the face of a

\section{REFERENCES}

1. Asmussen, E., AND M. Nielsen. Physiological deadspace and alveolar gas pressures at rest and during muscular exercise. Acta Physiol. Scand. 38: 1-121, 1956.

2. ÅsTRAND, P.-O. New records in human power. Nature London 176: 922-923, 1954.

3. Barcroft, J., C. A. Binger, A. V. Bock, J. H. Doggart, H. S. FoRBES, G. HARROP, J. C. MEAKINS, AND A. C. REDFIELD. Observations upon the effect of high altitude on the physiological processes of the human body, carried out in the Peruvian Andes, chiefly at Cerro de Pasco. Phil. Trans. R. Soc. London Ser. B 211: 351$480,1923$.

4. Bencowitz, H. Z., P. D. WAGner, AND J. B. West. Effect of change in $\mathrm{P}_{50}$ on exercise tolerance at high altitude: a theoretical study. J. Appl. Physiol.: Respirat. Environ. Exercise Physiol. 53: 1487-1495, 1982.

5. Cerretelli, P. Limiting factors to oxygen transport on Mount Everest. J. Appl. Physiol. 40: 658-667, 1976.

6. Christensen, E. H. Sauerstoffaufnahme und respiratorische Funktionen in grossen Höhen. Scand. Arch. Physiol. 76: 88-100, 1937.

7. Cotes, J. E. Ventilatory capacity at altitude and its relation to mask design. Proc. R. Soc. London Ser. B 143: 32-39, 1954.

8. Dejours, P. Mount Everest and beyond: breathing air. In: $A$ Companion to Animal Physiology, edited by C. R. Taylor, K. Johansen, and L. Bolis. New York: Cambridge Univ. Press, 1982.

9. Dill, D. B., S. Robinson, B. Balke, AND J. L. Newton. Work tolerance: age and altitude. J. Appl. Physiol. 19: 483-488, 1964.

10. Douglas, C. G., J. S. Haldane, Y. Henderson, and E. C. SCHNEIDER. Physiological observations made on Pike's Peak, Colorado, with special reference to adaptation to low barometric pressures. Phil. Trans. R. Soc. London Ser. B 203: 185-381, 1913.

11. EDWARDS, H. T. Lactic acid in rest and work at high altitude. $A m$. J. Physiol. 116: 367-375, 1936.

12. HABELER, P. Everest: Impossible Victory. London: Arlington, 1979.

13. HoustoN, C. S., AND R. L. RILEY. Respiratory and circulatory changes during acclimatization to high altitude. Am. J. Physiol. 149: 565-588, 1947.

14. MARET, K. H. Expedition to Mt. Everest, 1981: technical aspects. In: Hypoxia, Man at Altitude, edited by J. R. Sutton, N. L. Jones, greatly reduced inspired value. This is the most important of the three factors. Whereas we had previously assumed a $\mathrm{PCO}_{2}$ of 10 Torr on the summit, subject $C P$ reduced his to 7.5 Torr with striking gains in arterial and therefore tissue $\mathrm{PO}_{2}$. It is the combination of these three factors that just allows human beings to reach the highest point on earth.

We are indebted to all members of the expedition, especially John P. Evans, Deputy Leader-Climbing, and F. Duane Blume, $\mathrm{PhD}$., Deputy Leader-Logistics and Finance.

The expedition was supported by Public Health Service grant RO1HL-24335 and contract NO1-HR-2915 and grants from the American Alpine Club, American Lung Association, National Geographic Society, National Science Foundation, Servier Laboratories (Paris), The Explorers Club, and the US Army Research and Development Command.

Received 1 November 1982; accepted in final form 22 March 1983.

and C. S. Houston. New York: Thieme-Stratton, 1982.

15. MESSNER, R. The mountain. In: Everest: Expedition to the Ultimate. London: Kaye \& Ward, 1979, p. 174-18C

16. PETIT, J. M., J. MiLIC-EMILI, AND J. TroqUET. Travail dynamique pulmonaire et altitude. Rev. Med. Aerosp. 2: 276-279, 1963.

17. PIIPER, J., AND P. SCHEID. Model for capillary-alveolar equilibration with special reference to $\mathrm{O}_{2}$ uptake in hypoxia. Respir. Physiol. 46: 193-208, 1981.

18. Pollock, M. L. Submaximal and maximal working capacity of elite distance runners. Ann. NY Acad. Sci. 301: 310-322, 1977.

19. Pugh, L. G. C. E. Cardiac output in muscular exercise at $5,800 \mathrm{~m}$ (19,000 ft.). J. Appl. Physiol. 19: 441-447, 1964.

20. Pugh, L. G. C. E. Muscular exercise on Mt. Everest. J. Physiol. London 141: 233-261, 1958.

21. Pugh, L. G. C. E., M. B. Gill, S. Lahiri, J. S. Milledge, M. P. WARD, AND J. B. WEST. Muscular exercise at great altitude. $J$. Appl. Physiol. 19: 431-440, 1964.

22. Thoden, J. S., J. A. Dempsey, W. G. Reddan, M. L. Birnbaum, AND H. V. FORSTER. Ventilatory work during steady state response to exercise. Federation Proc. 28: 1316-1321, 1969.

23. Von Döbeln, W. A simple bicycle ergometer. J. Appl. Physiol. 7: 222-224, 1954.

24. West, J. B., P. H. Hackett, K. H. Maret, J. S. Milledge, R. M. Peters, JR., C. J. Pizzo, and R. M. Winslow. Pulmonary gas exchange on the summit of Mount Everest. J. Appl. Physiol.: Respirat. Environ. Exercise Physiol. 55: 678-687, 1983.

25. West, J. B., S. Lahiri, M. B. Gill, J. S. Milledge, L. G. C. E. Pugh, AND M. P. WARD. Arterial oxygen saturation during exercise at high altitude. J. Appl. Physiol. 17: 61'i-621, 1962.

26. West, J. B., S. Lahiri, K. H. Maret, R. M. Peters, and C. J. Pizzo. Barometric pressures at extreme altitudes on Mt. Everest: physiological significance. J. Appl. Physiol.: Respirat. Environ. Exercise Physiol. 54: 1188-1194, 1983.

27. West, J. B., ANd P. D. Wagner. Predicted gas exchange on the summit of Mt. Everest. Respir. Physiol. 42: 1-16, 1980.

28. West, J. B., AND P. D. WAGner. Pulmonary gas exchange. In: Bioengineering Aspects of the Lung, edited by J. B. West. New York: Dekker, 1977, vol. 5, p. 361-457. (Lung Biol. Health Dis. Ser.). 